JPdK Volume 3 Nomor 1 Tahun 2021 Halaman 65-70

JURNAL PENDIDIKAN dan KONSELING

Research \& Learning in Faculty of Education

\title{
Analisis Hubungan Perhatian orang Tua Dengan Prestasi Belajar Pada Masa Pandemi Covid - 19
}

\author{
Yanti Yandri Kusuma \\ Program Pendidikan Guru Sekolah Dasar \\ Fakultas Ilmu Pendidikan \\ Universitas Pahlawan Tuanku Tambusai \\ Email :zizilia.yanti@gmail.com
}

\begin{abstract}
Abstrak
Penelitian ini bertujuan untuk mengetahui hubungan perhatian orang tua dengan prestasi belajar siswa kelas III SD PT Tunggal Yunus Pertapahan Kabupaten Kampar pada masa Pandemi Covid-19. Penelitian ini adalah penelitian korelasional. Sampel dalam penelitian ini berjumlah 34 orang tua atau wali murid kelas III SD PT Tunggal Yunus Pertapahan Kabupaten Kampar pada masa Pandemi Covid-19. Teknik pengumpulan data atau alat pengumpulan data yang digunakan dalam penelitian ini adalah dengan menggunakan angket. Penelitian yang dimaksud ini dimaksud untuk mengetahui hubungan antara variabel $\mathrm{X}$ terhadap $\mathrm{Y}$ dengan menggunkan teknik korelasi product Moment. Dalam penelitian ini perhatian orangtua dikelompokkan dalam 4 kategori, yaitu sangat sering, sering, jarang dan tidak pernah. Yang menyatakan sangat sering sebanyak 20 orang atau $44.22 \%$, yang menyatakan Sering sebanyak 10 orang atau $25.50 \%$, yang menyatakan jarang sebanyak 3 orang atau $6.10 \%$ dan yang menyatakan tidak pernah sebanyak 2 orang atau $3.05 \%$. Dalam penelitian ini prestasi belajar siswa dikelompokkan dalam 4 kategori, yaitu amat baik, baik, cukup baik dan sangat tidak baik. Nilai siswa yang amat baik sebanyak 10 orang atau $18.64 \%$ dan nilai Baik sebanyak 35 orang atau 60.36\%. Artinya nilai siswa dalam masa Pandemi Covid-19 tetap bagus. Perhatian orang tua dengan kedisiplinan siswa memiliki hubungan yang signifikan dimana thitung $>$ ttabel. Perhatian orang tua memiliki hubungan yang signifikan dengan prestasi belajar siswa dimana thitung $>$ ttabel atau $4.578>1.000$, maka ditolak artinya ada hubungan yang signifikan antara perhatian orangtua dengan prestasi belajar siswa
\end{abstract}

Kata Kunci: Analisis Perhatian Orang Tua, Prestasi Belajar

\begin{abstract}
This study aims to determine the relationship between parental attention and learning achievement of third grade students of SD PT Tunggal Yunus Pertapahan in Kampar Regency during the Covid-19 Pandemic. This research is a correlational research. The sample in this study amounted to 34 parents or guardians of grade III SD PT Tunggal Yunus Pertapahan in Kampar Regency during the Covid-19 Pandemic. The data collection technique or data collection tool used in this study was to use a questionnaire. The research in question is intended to determine the relationship between the variable $\mathrm{X}$ to $\mathrm{Y}$ by using the product moment correlation technique. In this study, parental attention was grouped into 4 categories, namely very often, frequently, rarely and never. Those who stated very often were 20 people or $44.22 \%$, who stated that often were 10 people or $25.50 \%$, who said that they were rarely as many as 3 people or $6.10 \%$ and those who said they had never were 2 people or $3.05 \%$. In this study, student learning achievement was grouped into 4 categories, namely very good, good, good enough and very bad. Very good student scores were 10 people or $18.64 \%$ and Good grades were 35 people or 60.36\%. This means that student scores during the Covid-19 Pandemic were still good. Parents' attention with student discipline has a significant relationship where $\mathrm{t}$ count $>\mathrm{t}$ table. Parents' attention has a significant relationship with student achievement where tcount> ttable or $4.578>1,000$, then being rejected means that there is a significant relationship between parental attention and student achievement.
\end{abstract}

Keywords: Analysis of Parents' Attention, Learning Achie 


\section{PENDAHULUAN}

Pendidikan merupakan bimbingan atau pertolongan yang diberikan oleh orang dewasa kepada perkembangan anak untuk mencapai kedewasaanya dengan tujuan agar anak cukup cakap melaksanakan tugas hidupnya sendiri tidak dengan bantuan orang lain". Lingkungan keluarga merupakan media pertama dan utama yang secara langsung atau tidak langsung berpengaruh terhadap perilaku dalam perkembangan anak. Pendidikan keluarga adalah fundamen atau dasar dari pendidikan anak selanjutnya.

Hasil-hasil pendidikan yang diperoleh anak dalam keluarga menentukan pendidikan anak selanjutnya, baik di sekolah maupun dalam masyarakat. pendidikan adalah usaha sadar dan terencana untuk memberikan bimbingan atau pertolongan dalam mengembangkan potensi jasmani dan rohani yang diberikan oleh orang dewasa kepada anak untuk mencapai kedewasaanya serta mencapai tujuan agar anak mampu melaksanakan tugas hidupnya secara mandiri..

Haditomo dkk (1980 : 4), mengatakan "Prestasi Belajar adalah kemampuan seseorang sebagai hasil belajar". Dewa Ketut Sukardi (1983 : 51), menyatakan "Untuk mengukur Prestasi Belajar menggunakan tes prestasi yang dimaksud sebagai alat untuk mengungkap kemampuan aktual sebagai hasil belajar atau learning". Menurut Sumadi Suryabrata (1987 : 324), "Nilai merupakan perumusan terakhir yang dapat diberikan oleh guru menganai kemajuan atau Prestasi Belajar Siswa selama masa tertentu". Dengan nilai rapor, kita dapat mengetahui Prestasi Belajar Siswa. Siswa yang nilai rapornya baik dikatakan prestasinya tinggi, sedangkan yang nilainya jelek dikatakan Prestasi Belajar nya rendah. Belajar yang efektif dapat membantu siswa untuk meningkatkan kemampuan yang diharapkan sesuai dengan tujuan instruksional yang ingin dicapai.

Untuk meningkatkan Prestasi Belajar yang baik perlu diperhatikan kondisi internal dan eksternal. Kondisi internal dalah kondisi atau situasi yang ada dalam diri siswa, seperti kesehatan, keterampilan, kemapuan dan sebaginya. Kondisi eksternal adalah kondisi yang ada di luar diri pribadi manusia, misalnya ruang belajar yang bersih, sarana dan prasaran belajar yang memadai.

Pengetahuan, pengalaman dan keterampilan yang diperoleh akan membentuk kepribadian siswa, memperluas kepribadian siswa, memperluas wawasan kehidupan serta meningkatkan kemampuan siswa. Bertolak dari hal tersebut maka siswa yang aktif melaksanakan kegiatan dalam pembelajaran akan memperoleh banyak pengalaman. Dengan demikian siswa yang aktif dalam pembelajaran akan banyak pengalaman dan Prestasi Belajarnya meningkat. Sebaliknya siswa yang tidak aktif akan minim/sedikit pengalaman sehingga dapat dikatakan Prestasi Belajarnya tidak meningkat atau tidak berhasil.

Pelaksanaan pembelajaran sangat memerlukan perhatian dan keseriusan, perhatian dari orang tua memberikan dengan nilai positif terhadap keberhasilan pembelajaran itu sendiri. Pendidikan dalam keluarga memberikan pengaruh yang besar terhadap ketercapaian tujuan yang ingin diperoleh oleh si anak. Sebagaimana diketahui bahwa agama sebagai dasar pembentukan kualitas diri sangat berperan dalam menumbuh kembangkan kesadaran, sikap dan perilaku anak.

Karena itu pendidikan menjadi sangat sentral dalam mewujudkan manusia yang beriman dan bertaqwa sebagaimana yang diharapkan. Peningkatan kemampuan belajar bagi anak salah satunya berupa kegiatan belajar di rumah. Penulis dapat menyimpulkan bahwa anak yang mendapatkan perhatian dari orang tua pada saat belajar di rumah, akan memperoleh prestasi belajar yang lebih tinggi pada masa covid-19. Melalui kegiatan ini diharapkan mampu menjawab tantangan intelektual dalam menghadapi era globalisasi dewasa ini. Cara belajar anak di rumah merupakan tanggung jawab orang tua. Salah satu bentuk perhatian orang tua adalah dengan cara memberi perlengkapan belajar termasuk di dalamnya sarana dan materi belajar anak.

Dalam Analisis Keberhasilan siswa dalam belajar dipengaruhi oleh adanya perhatian orang tua terhadap cara belajar anak di rumah. Oang tua lebih banyak mempunyai kesempatan untuk membimbing anaknya belajar dari pada guru di sekolah, dikarenakan pada saat ini dalam keadaan Covid-19. Sebagai orang tua harus memanfaatkan keadaan tersebut agar anak mempunyai prestasi yang baik di sekolah. Akhir-akhir ini berbagai negara di dunia, tengah dikejutkan dengan wabah suatu penyakit yang disebabkan oleh virus bernama corona atau lebih dikenal dengan istilah covid- 19 (Corona Virus Diseases-19). 
Virus ini awalnya mulai berkembang di Wuhan, China. Wabah virus ini memang penularannya sangat cepat menyebar ke berbagai negara di dunia. Sehingga oleh World Health Organization (WHO), menyatakan wabah penyebaran virus covid-19 sebagai pandemi dunia saat ini. Pemerintah menerapkan kebijakan yaitu Work From Home (WFH). Kebijakan ini merupakan upaya yang diterapkan kepada masyarakat agar dapat menyelesaikan segala pekerjaan di rumah. Pendidikan di Indonesia pun menjadi salah satu bidang yang terdampak akibat adanya pandemi covid-19 tersebut.

Dengan adanya pembatasan interaksi, Kementerian Pendidikan di Indonesia juga mengeluarkan kebijakan yaitu dengan meliburkan sekolah dan mengganti proses Kegiatan Belajar Mengajar (KBM) dengan menggunakan sistem dalam jaringan (daring). Dengan menggunakan sistem pembelajaran secara daring ini, terkadang muncul berbagai masalah yang dihadapi oleh siswa dan guru, seperti materi pelajaran yang belum selesai disampaikan oleh guru kemudian guru mengganti dengan tugas lainnya.

Hal tersebut menjadi keluhan bagi siswa karena tugas yang diberikan oleh guru lebih banyak. Adanya pandemi covid-19 juga memberikan hikmah yang lainnya. Pembelajaran yang dilakukan di rumah, dapat membuat orang tua lebih mudah dalam memonitoring atau mengawasi terhadap perkembangan belajar anak secara langsung. Orang tua lebih mudah dalam membimbing dan mengawasi belajar anak dirumah dengan membimbing pembelajaran yang di berikan oleh guru disekolah melalui online atau wa group dikelas siswa masingmasing berdasarkan kelasnmya.

Ini akan menimbulkan komunikasi yang lebih intensif dan akan menimbulkan hubungan kedekatan yang lebih erat antara anak dan orang tua. Orang tua dapat melakukan pembimbingan secara langsung kepada anak mengenai materi pembelajaran yang belum dimengerti oleh anak. Dikarenakan orang tua adalah institusi pertama dalam pendidikan anak. Dalam kegiatan pembelajaran secara online yang diberikan oleh guru, maka orang tua dapat memantau sejauh mana kompetensi dan kemampuan anaknya.

Kemudian ketidakjelasan dari materi yang diberikan oleh guru, membuat komunikasi antara orang tua dengan anak semakin terjalin dengan baik. Orang tua dapat membantu kesulitan materi yang dihadapi anak. Perhatian merupakan kegiatan yang dilakukan seseorang dalam hubungannya dengan pemilihan rangsangan yang datang dari lingkungannya. Perhatian juga sebagai salah satu aktivitas psikis, dapat dimengerti sebagai keaktifan jiwa yang di pertinggi. Dengan kata lain, perhatian merupakan pemusatan atau konsentrasi dari seluruh aktivitas individu yang di tujukan kepada suatu suatu sekumpulan obyek. Kalau individu sedang memperhatikan suatu benda misalnya, ini berarti seluruh aktivitas individu di curahkan atau di konsentrasikan pada benda tersebut.

Perhatian itu sangat di pengaruhi oleh perasaan dan suasana hati, serta di tentukan oleh kemauan. Sesuatu yang dianggap luhur, mulia, dan indah akan sangat mengikat perhatian. Demikian pula sesuatu hal yang dapat menimbulkan rasa nyeri dan ketakutan, akan mencekam perhatian. Sebaliknya, segala sesuatu yang membosankan, sepele, dan terus menerus berangsung tidak akan bisa mengikat perhatian.

Berdasarkan hasil pengamatan dan wawancara penulis terhadap siswa dan Guru kelas III di SD PT Tunggal Yunus Pertapahan Bangkinang Kabupaten Kampar pada masa Pandemi Covid-19 ditemukan fenomena sebagai berikut:

1) sebagian tugas-tugas yang diberikan kepada anak tidak diparaf orang tua seperti Pekerjaan Rumah (PR).

2) Tugas yang diberikan kepada anak kebanyakan tidak selesai, terbukti banyak PR (pekerjaan Rumah) yang salah dalam pengerjaannya sehingga siswa menyelesaikan PR tersebut di sekolah dengan terburu buru.

3) Adanya sebagian siswa ketika pergi ke sekolah ada yang berpakaian tidak lengkap dan bukubuku serta peralatan yang tidak lengkap juga.

4) Orang tidak mengingkat anaknya untuk belajar dengan mengikuti jadwal pandemi covid - 19 dengan membimbingnya.

Dapat dianalisis fenomena di atas, merupakan suatu yang ironis berkaitan dengan prestasi belajar anak. Analisis hubungan perhatian orang tua siswa kelas III SD Tunggal Yunus Pertapahan Kabupaten Kampar pada masa Covid-19 terhadap prestasi belajar belum diterapkan sebagian orang tua dirumah.

\section{METODOLOGI PENELITIAN}

Penelitian dilaksanakan di SD PT Tunggal Yunus Pertapahan Kabupaten Kampar pada masa Covid-19. Penelitian ini adalah penelitian kuantitatif dengan menggunakan teknik korelasional. Penelitian dengan teknik korelasional untuk mengetahui ada tidaknya 
hubungan antara dua variabel (Sugiyono, 2013:5) Populasi yang akan diambil pada penelitian ini adalah seluruh orang tua yang anaknya duduk di SD Tunggal Yunus Pertapahan Bangkinang Kabupaten Kampar pada masa Pandemi Covid-19 yakni berjumlah 45 orang yang terdiri dari kelompok belajar (Va dan $\mathrm{Vb}$ ). Sehingga sampel dalam penelitian ini berjumlah 35 orang tua atau wali murid kelas III SD Tunggal Yunus Pertapahan Kabupaten Kampar pada masa Pandemi Covid-19.

Sumber data penelitian terdiri dari dua yaitu data primer. Data penelitian yang diambil langsung dari orang tua siswa kelas III SD PT Tunggal Yunus Pertapahan Kabupaten Kampar pada masa Pandemi Covid-19 yaitu sebanyak 35 orang yaitu data tentang perhatian orang tua. Data sekunder Yaitu informasi yang diperlukan untuk menyusun data-data penelitian baik berupa, konsep, defenisi, ataupun teori-teori yang dapat dipergunakan untuk menjelaskan permasalahan yang akan dilaksanakan melalui penelitian ini. Teknik pengumpulan data yang digunakan dalam penelitian ini adalah dengan menggunakan angket. Penelitian ini untuk mengetahui hubungan antara variabel $\mathrm{X}$ terhadap $\mathrm{Y}$ dengan menggunkan teknik korelasi product Moment yakni untuk mengetahui derajat hubungan korelasi antara dua variabel (Person dalam Buchari, $2007: 138)$

\section{HASIL PENELITIAN DAN PEMBAHASAN}

Hasil penelitian dapat diketahui bahwa yang menyatakan sangat sering sebanyak 20 orang atau $44.22 \%$, yang menyatakan Sering sebanyak 10 orang atau $25.50 \%$, yang menyatakan jarang sebanyak 3 orang atau $6.10 \%$ dan yang menyatakan tidak pernah sebanyak 2 orang atau $3.05 \%$. Analisisnya orangtua siswa kelas III SD Tunggal Yunus Pertapahan Kabupaten Kampar Pada Masa Pandemi Covid-19 memberikan perhatian kepada anaknya dalam meningkatkan prestasi belajar. Orangtua yang sangat sering dan sering memberikan perhatian kepada anaknya memberikan pengaruh prestasi belajar anak di sekolah yaitu memiliki nilai prestasi belajar tinggi.

Orangtua yang sering memberikan perhatian kepada anak sebanyak $44.22 \%$ dan anak mendapatkan prestasi belajar dengan amat baik yaitu sebanyak $25.50 \%$. Sedangkan orangtua yang memberikan perhatian kepada anak dengan sering sebanyak $25.60 \%$ dan mengakibatkan anak mendapatkan prestasi belajar yang baik yaitu sebanyak 60.26\%. Prestasi belajar siswa yang Sangat Sering sebanyak 10 orang atau $189.54 \%$ dan nilai Sering sebanyak 35 orang atau $60.36 \%$. Artinya nilai siswa dalam masa Pandemi Covid-19 tetap bagus.

Hal ini dikarenakan di rumah siswa diberikan perhatian oleh orangtua untuk selalu belajar meskipun di rumah Di Analisis bahwa perhatian orangtua memiliki hubungan yang signifikan dengan Prestasi Belajar Siswa. Hal ini ditunjukkan dari hasil perhitungan korelasi pada perhatian orangtua dengan $\mathrm{t}_{\text {hitung }}=4.478$ dan sumbangan (kontribusi) sebesar $25.5 \%$.

Pembahasan ini dilakukan berdasarkan pertanyaan penelitian yaitu bagaimana perhatian orang tua dengan prestasi belajar siswa kelas III SD Tunggal Yunus pertapahan Kabupaten Kampar pada masa Pandemi Covid-19.

Berdasarkan Analisis data di atas, terdapat 5 bentuk perhatian yang diberikan seperti memberikan dorongan (motivasi belajar anak), membimbing belajar anak, memberi teladan yang baik, komunikasi yang lancar dengan anak dan memenuhi kelengkapan belajar anak.

Dalam penelitian ini perhatian orangtua dikelompokkan dalam 4 kategori, yaitu sangat sering, sering, jarang dan tidak pernah. Yang menyatakan sangat sering sebanyak 20 orang atau $44.22 \%$, yang menyatakan Sering sebanyak 10 orang atau $25.50 \%$, yang menyatakan jarang sebanyak 3 orang atau $6.10 \%$ dan yang menyatakan tidak pernah sebanyak 2 orang atau $3.05 \%$. Artinya orangtua siswa kelas III SD TunggalYunus Pertapahan Kabupaten Kampar Pada Masa Pandemi Covid-19 memberikan perhatian kepada anaknya untuk meningkatkan prestasi belajar.

Menurut Kartini Kartono (1996:111) perhatian itu merupakan reaksi umum dari organisme dan kesadaran yang menyebabkan bertambahnya aktivitas, daya konsentrasi dan pembatasan kesadaran terhadap satu obyek. Orang tua perlu mengawasi pendidikan anak-anaknya, sebab tanpa adanya pengawasan yang kontinu dari orang tua besar kemungkinan pendidikan anak tidak akan berjalan lancar.

Pengawasan orang tua tersebut dalam arti mengontrol atau mengawasi semua kegiatan atau aktivitas yang dilakukan oleh anak secara langsung maupun tidak langsung. Berdasarkan hasil penelitian yang telah dikemukakan sebelumnya, Prestasi Belajar Siswa di paparkan pembahasan sesuai dengan pertanyaan penelitian yang telah diajukan. Dalam penelitian ini prestasi belajar siswa dikelompokkan dalam 4 kategori, yaitu amat baik, baik, cukup baik dan sangat tidak baik. Nilai siswa yang amat baik sebanyak 10 orang atau $18.64 \%$ dan nilai Baik sebanyak 35 orang atau $60.36 \%$. Artinya 
nilai siswa dalam masa Pandemi Covid-19 tetap bagus.

Hasil tersebut sesuai dengan teori Slameto (2013) yang menjelaskan bahwa salah satu faktor yang mempengaruhi keberhasilan prestasi belajar anak adalah peran lingkungan yang salah satunya pengaruh perhatian orang tua. Perhatian yang cukup dan perlakuan orang tua yang bijaksana terhadap anak, akan berdampak pada kemampuan pengembangan potensi diri anak yang melahirkan motivasi belajar yang tinggi dan kemampuan konsentrasi dalam aktivitas belajarnya yang akhirnya berpengaruh kepada pencapaian prestasi belajar siswa.. Hal tersebut ditunjukan dengan nilai signifikansi (sig) pada hasil perhitungan lebih kecil dari pada 0.05 , yaitu $0.005(0.005<0.05)$, dan melalui hasil yang ditunjukkan dengan nilai Fhitung 7,515 > Ftabel 3,05. Sehingga terdapat hubungan yang signifikan antara perhatian orangtua dan prestasi belajar siswa.

\section{SIMPULAN}

Berdasarkan hasil penelitian dan
pembahasan dapat diambil simpulan sebagai berikut:

1. Bentuk perhatian orangtua di SD PT Tunggal Yunus Pertapahan Kabupaten Kampar ada 5 seperti memberikan dorongan (motivasi belajar anak), membimbing belajar anak, memberi teladan yang baik, komunikasi yang lancar dengan anak dan memenuhi kelengkapan belajar anak. Dalam penelitian ini perhatian orangtua dikelompokkan dalam 4 kategori, yaitu sangat sering, sering, jarang dan tidak pernah. Yang menyatakan sangat sering sebanyak 20 orang atau $44.22 \%$, yang menyatakan Sering sebanyak 10 orang atau $25.50 \%$, yang menyatakan jarang sebanyak 3 orang atau $6.10 \%$ dan yang menyatakan tidak pernah sebanyak 2 orang atau $3.05 \%$.

Dalam penelitian ini prestasi belajar siswa dikelompokkan dalam 4 kategori, yaitu amat baik, baik, cukup baik dan sangat tidak baik. Nilai siswa yang amat baik sebanyak 10 orang atau $18.64 \%$ dan nilai Baik sebanyak 35 orang atau $60.36 \%$.

2. Perhatian orang tua dengan kedisiplinan siswa memiliki hubungan yang signifikan dimana $t_{\text {hitung }}>t_{\text {tabel }}$. Perhatian orang tua memiliki hubungan yang signifikan dengan prestasi belajar siswa dimana $t_{\text {hitung }}>t_{\text {tabel }}$ atau $5.578>2.000$, maka ditolak artinya ada hubungan yang signifikan antara perhatian orangtua dengan prestasi belajar siswa.

\section{DAFTAR PUSTAKA}

Abu Ahmadi, Psikologi Perkembangan, Jakarta: Rineka Cipta, 2001.

Agus Suprijono, Cooperative Learning (Teori \& Aplikasi Paikem), Yogyakarta: Pustaka Pelajar, 2010.

Anne Ahira, Faktor-Faktor yang mempengaruhi Prestasi Belajar Siswa, http://www.anneahira.com, online, diakses tanggal 29/01/2012.

Ahmadi, A dan Joko Tri Pasetya. 2005. Strategi Belajar Mengajar. Pustaka Setia. Bandung.

Ahmadi, A dan Supriyono. 2004. Psikologi Belajar. Jakarta: Rineka Cipta .

Ahmadi, A. 2003. Psikologi Umum. Jakarta. Rineka cipta

Arikunto, S. 1998. Prosedur Penelitian Suatu Pendekatan Praktek. Jakarta. Rineka cipta

Buchari. 2007. Belajar Mudah Penelitian. Jakarta:Alfabeta

Baharuddin, 2010. Teori Belajar dan Pembelajaran. Jogjakarta: Arruz.

Depdikbud. 2002. Kamus Besar Bahasa Indonesia. Jakarta : Balai Pustaka.

Desmita. 2006. Psikologi Perkembangan. Bandung. Rosda

Dimyati dan Mudjiono. 2002. Belajar dan Pembelajaran. Jakarta. Rineka Cipta.

Djamarah, S. B .2002. Psikologi belajar. Jakarta. Rineka cipta. Jakarta. Rineka cipta.

Muhibbin Syah, Psikologi Pendidikan dengan Pendekatan Baru, Jakarta: PT. Remaja Rosdakarya, 2007.

Rina Puspitasari (2020). Hikmah Pandemi Covid-19 Bagi Pendidikan Di Indonesia Diterbitkan tanggal 23 April 2020. https://iain- 
surakarta.ac.id/hikmah-pandemi-covid-19-

bagi-pendidikan-di-indonesia/

Slameto, Belajar dan Faktor-faktor yang mempengaruhinya, Jakarta: Rineka Cipta, 2003.

Sofchah Sulistyowati, Cara Belajar yang Efektif dan Efisien, Pekalongan: Cinta Ilmu, 2001. 